\title{
Analysis of troops groupings in modern local wars and armed conflicts
}

\author{
Anton Tkachenko ${ }^{1}$ A; Ruslan Cherevko ${ }^{2}$; ; Aleksandr Yvashchuk ${ }^{3}$ A; \\ Anton Nykytenko ${ }^{4} \mathrm{~A}$ \\ A National Defence University of Ukraine named after Ivan Cherniachovskyi, 28, Povitroflotsky, ave, Kyiv, 03049, Ukraine
}

Received: February 01, 2021 | Revised: February 21, 2021 | Accepted: February 28, 2021

DOI: $10.33445 / s d s .2021 .11 .1 .11$

\begin{abstract}
The results of the analysis of recent military conflicts convincingly show that the forms and methods of the armed forces application are changing and improving. Scientific and technological progress, the rapid development of information technology, the growing role of high-precision weapons, increasing the effectiveness of intelligence, intensive automation of command and control systems change the nature of modern warfare and are having a steady impact on operational arts, including the need to further improve management theory. In modern military conflicts, new trends in the development of an armed warfare have emerged, which affect the construction of the armed forces, the development of forms and methods of their application. At the same time, there are deviations from the classical views on the military operation execution.

The article presents some features of modern conflicts, shows that the main task in modern wars is to gain and maintain information superiority over the enemy through the use of a single information and communication space by the troop's groupings.
\end{abstract}

Key words: military conflict, grouping of troops, armed warfare, offensive operation.

\section{Introduction}

During the local wars and military conflicts of the last decade, considerable combat experience has been accumulated. The analysis indicates that the military-technical capabilities of countries, the quantity and quality of their weapons and military equipment significantly affect the preparation and methods of warfare, the course and outcome of the combat activities.

The course of the military conflicts of the last decade proves that the importance of armaments and military equipment, in which the latest technologies are implemented, is growing year by year. At the same time, the armed warfare has acquired a large-scale, aerospace and ground highly maneuverable features with simultaneous combat operations on land, in the air, space and at sea with the use of aviation, missile weapons, space assets, high-precision weapons (HPW), electronic warfare and electronic warfare control systems, special forces and airborne assault troops (Manachinskii A., 2005; Mihajlov A., 2004; Myasnikov V.).

The prototype of such conflicts is the war in the Persian Gulf, Afghanistan, Yugoslavia, the conflict in Chechnya.

The Gulf War is a military conflict at the crossroads of two eras. It marked the transition to the wars of the new generation, the wars of the space age. Another fundamental difference between this war and previous local wars is that, for the first time, the latest forms of the HPW were used on a large scale.

The significant advantage of NATO troops in the air strikes had allowed them $t$ to destroy the

\footnotetext{
${ }^{1}$ Corresponding author: Candidate of Technical Sciences, Senior Researcher, Deputy Head of the Science and Technology Management Centre Head of Scientific Department, e-mail: NOUAntonio@ukr.net, ORCID: 0000-0002-1620-4206

2 PhD student, e-mail: cherepruslan2017@gmail.com, ORCID: 0000-0003-0414-0695

${ }^{3}$ PhD student, e-mail: Gu2k1984@gmail.com, ORCID: 0000-0002-0659-3201

${ }^{4}$ PhD student, e-mail: sashik-ivashchuk84@ukr.net, ORCID: 0000-0002-8189-6472
} 
industrial centers and other economically important facilities of the state, large groups of troops simultaneously throughout the territory and to implement the basic provisions of the concept of "air-ground operation" in practice.

First of all, these were the Tomahawk naval and air-based guided cruise missiles, air-to-ground cruise missiles, guided aerial bombs, anti-radar missiles (ARMs) with an advanced guidance system "Alarm", AAC which are capable of striking the enemy ballistic missiles. In the war with Iraq, HPW long-range systems have allowed multinational forces to create zones of destruction, destroying field fortifications, armored vehicles, aircraft (helicopters) on the ground, radar stations (radars), communications, missiles, control points, command posts, rear facilities and other important targets.

It is believed that the wars of the new era will not be a barrage of fire, as was the case before, but a "surgical operation" to destroy the most important enemy objects with the help of the WTO (Tkachev V., 2007; Kuchumov S., 2009).

Thus, military theorists have concluded that the war in the Persian Gulf has ushered in a new era of armed conflicts: the scale of the war is the age of space wars, the means of warfare is the age of high-tech wars.

\section{Material and methods}

Analysis of recent research and publications (Strizhevs'kij V. V., 2006; Tolubko V.B., 2002; Zaika V. F., 2010; Girin A. V.) shows that the new generation of armed conflicts has the following features: widespread use of the latest weapons and high-precision weapons systems, air attack, intelligence and electronic warfare; improving the efficiency and quality of command and control as a result of the transition to a global integration of automated control systems for troops and weapons; high degree of simultaneous destruction of troops and facilities to the full depth of hostilities, rapid maneuvering of troops and fire, the use of mobile groups of troops.

The purpose of the article is to analyze the approaches that exist in the armies of the world's leading countries, to determine the possible composition and nature of the actions of offensive groups in modern wars and armed conflicts.

\section{Results and discussion}

The development of military art, forms and methods of using troops groupings in modern military conflicts, has led to some questions affecting modern views on the use of armed forces and determine new requirements for the deployment of groups of troops to conduct operations. Therefore, conducting research to determine the main trends in the development of armed struggle, forms and methods of application of groups of troops, their composition on the basis of analysis of modern experience is relevant.

The grouping of troops in military conflicts in recent decades has generally been created in advance, in peacetime or in a special period, and the full deployment and reinforcement has been created at the beginning and during the armed conflict.

Considering modern military conflicts
(Voenno-politicheskij, 2001; Kulikov A., 2007; Operacziya OVS, 2019), they can be divided into two main groups of armed conflicts: the first an armed conflict involving the armed forces of two or more states (international armed conflict, armed conflict at the state border); the second is an armed conflict in which the armed forces are opposed by irregular armed formations within the territory of one state, usually with the support of external states (internal armed conflict).

The first conditional group includes fighting in the Persian Gulf, former Yugoslavia, and Iraq.

Thus, Operation Desert Storm (Gareev M., 2003) was preceded by a well-organized informational and psychological operation, during which the Iraqi leadership was misled as to the timing of combat actions. The peculiarity of the use of troops groupings during the 
operation was that the solution of the main tasks of defeating the enemy to the full depth of its operational construction was entrusted to strategic, tactical and deck aircraft with extensive use of fire support helicopters and various modifications of cruise missiles.

The final stage of the operation was supposed to be achieved by conducting an airto-ground offensive operation "Desert Sword". The plan of the operation was to achieve not only operational but also strategic success in a short time, using the results of the air offensive operation.

Features of the use of multinational forces in the offensive operation "Desert Sword" include:

large-scale operative camouflage measures to mislead the enemy as to the direction of the main and other strikes;

strikes by troops on the entire operational, and in some areas on the strategic depth;

widespread use of airborne troops;

conducting simultaneous strikes in several areas.

For this purpose, appropriate groups of troops were created, taking into account the specifics of their use. A comparative analysis of the composition of troops groups of the parties is given in table 1.

Table 1 - Composition of troops groupings of the parties

\begin{tabular}{|c|c|c|c|c|c|c|}
\hline Parties & Personnel & Planes & Helicopters & Tanks & $\begin{array}{c}\text { Artillery } \\
\text { (Mortars) }\end{array}$ & Ships \\
\hline \multicolumn{7}{|c|}{ Composition of troops of the parties as of January 1991 } \\
\hline Multinational forces & 677000 & 1880 & 500 & 3988 & 2500 & 88 \\
\hline The Iraqi Army & 554000 & 348 & - & 4864 & 6300 & - \\
\hline \multicolumn{7}{|c|}{ Composition of troops groupings of the parties after increasing efforts } \\
\hline Multinational forces & 731000 & 2522 & 2000 & 4322 & 3100 & 107 \\
\hline The Iraqi Army & 698000 & 648 & - & 5378 & 8000 & - \\
\hline
\end{tabular}

The results of data analysis table 1 . show that the overall quantitative ratio of the forces of the parties did not guarantee the success of the offensive operation of the multinational force, but the specifics of the use of strikes allowed to achieve the goal of the operation.

Further improvements in the use of troop groups took place during the NATO military operations against Yugoslavia (1999). The combat actions were supposed to begin with an air offensive operation "Allied Force". The peculiarity of the operation was that it was started with the minimum necessary forces, which allowed to reduce the financial costs of its implementation. The build-up of forces and resources was carried out in parallel with the conduct of combat actions throughout the operation.

To conduct Operation Allied Force, a strike air force and a naval group of NATO troops (forces) were created (the composition of the groups of troops of the parties is given in Table 2). A feature of the use of groups in the operation was the widespread use of unmanned aerial vehicles for reconnaissance. The operation was carefully planned taking into account a significant number of possible scenarios.

Table 2 - Composition of troops groupings of the parties

\begin{tabular}{|c|c|c|c|c|c|}
\hline Parties & Planes & Helicopters & CMBS & CMAB & Ships \\
\hline \multicolumn{7}{|c|}{ Composition of troops of the parties as of March 1999 } \\
\hline NATO & 370 & 90 & 240 & 88 & 20 \\
\hline Yugoslavian Army & 250 (15-MIG-29) & 60 & - & - & - \\
\hline \multicolumn{2}{|c|}{ Composition of troops groupings of the parties after increasing efforts } \\
\hline NATO & 590 & 120 & 320 & 102 & 32 \\
\hline Yugoslavian Army & 140 (7- MIG-29) & 44 & - & - & - \\
\hline
\end{tabular}

As can be seen from table. 2, taking into account a number of qualitative indicators (level 
of perfection of equipment and armaments, logistics, etc.), the ratio of NATO and Yugoslav forces was 5: 1 . during the operation. As a result, the balance of power (taking into account the losses of Yugoslavia) changed to $30: 1$.

Assessing the specifics of the use of weapons and ammunition, we can conclude that Operation Allied Force marked the beginning of a fundamentally new stage in the development of technologies in the field of air missile and ammunition, the essence of which is the transition from weapons with laser guidance to inertial weapons to navigation satellite guidance system. Carrying out a full-scale air operation allowed NATO Command to solve two tasks that are naturally related: first, to realistically assess the correctness of the chosen route and make the necessary adjustments; second, to clean up their arsenals of obsolete types of ammunition with maximum benefit.

The next operation, Freedom of Iraq, took place in 2003 in the Persian Gulf and had a clear air-ground character. Unlike the 1991 operations and the air offensive in Yugoslavia, this operation lacked powerful massive missile strikes. The peculiarities of the use of troops were the application of "point" strikes by means of air and naval bases. At the same time, preference was given to the use of highprecision weapons and practical testing of promising high-precision ammunition. Another feature of the operation was the use of a ground group of troops almost from the very beginning. The offensive began with an air strike, with no fire support. It was assumed that the group's offensive against the Iraqi capital would be conducted in the desert, without engaging in combat with the Iraqi army.

But, despite the quality and advanced planning of the operation, the composition of groups of troops did not remain the same during its preparation and conduct. The composition of the groups of troops of the parties is presented in table. 3.

Table 3 - Composition of groups of troops of the parties

\begin{tabular}{|c|c|c|c|c|c|c|}
\hline Parties & Planes & Helicopters & BBM & $\begin{array}{c}\text { CMBS, } \\
\text { CMAB }\end{array}$ & $\begin{array}{c}\text { Artillery } \\
\text { (Mortars) }\end{array}$ & Ships \\
\hline \multicolumn{7}{|c|}{ Composition of the groups of troops of the parties as of April 30, 2003 } \\
\hline NATO & 1180 & 850 & 3200 & 565 & 1300 & 85 \\
\hline Army of Iraq & 75 & 180 & 2180 & - & 2260 & - \\
\hline \multicolumn{7}{|c|}{ Composition of groups of troops of the parties after increasing efforts } \\
\hline NATO & 1310 & 1100 & 4322 & 835 & 2170 & 115 \\
\hline Army of Iraq & 300 & 400 & 5227 & - & 8000 & - \\
\hline
\end{tabular}

As can be seen from table 3, the success of NATO's air offensive was ensured by the widespread use of high-precision weapons and aircraft.

After the war, the military press debated the question - perhaps the tactics are dying out? After all, there was almost no armed struggle on a tactical scale in the Persian Gulf. There were no close battles on the ground or in the air. Despite this, the discussion showed that most of its participants say that the tactics will remain. But the battles of the future will be very different from the battles of the past.

The battle of the past is melee. The main tasks in such a battle were determined by the actions of infantry and tanks with inevitable heavy losses. Such a battle is characterized by a long positional confrontation of the parties, massaging forces on a narrow section of the front in order to break through the positional defence and a clear division of battle actions to offensive and defencive.

The battle of the future is a remote battle. Crucial in such a battle is the fire of long-range high-precision weapons. The maneuver will win in all types of combat. The principle of creating a massive advantage of forces will retain its significance, primarily in the form of concentration of fire efforts. There will be erasure of clear boundaries between offensive 
and defense, frequent transitions from one type of combat to another.

The second conditional group includes the fighting of the Russian Federation troops in the Chechen Republic and the North Caucasus, the Russian-Georgian military conflict. In these conflicts, the use of groups of troops differed significantly from the classical ones.

A characteristic feature of both the first and second operations in the Chechen Republic was that they were largely asymmetric. The created groups of troops conducted both offensive, defensive and special actions. The lack of a clear front line, the focal nature of combat actions in certain areas (zones) of responsibility, necessitated the non-classical use of a group of troops, which was based on raids, maneuvers, ambushes, search and strike, assault, security, guard actions, actions of troops to block and isolate the enemy.

A significant number of tasks in these operations was assigned to the rocket troops and artillery. For the first time, they applied in practice the method of zonal-object fire, the essence of which was to provide broad rights and opportunities to the ground troops commander, in the organization of fire support on the principle of "detection - destruction". The number of troops groupings of the parties in the first and second operations in the Chechen Republic is given in table 4 .

Table 4 - Composition of forces of the parties to the armed conflict in the Chechen Republic

\begin{tabular}{|c|c|c|c|c|c|c|c|}
\hline \multicolumn{2}{|c|}{ Parties } & Personnel & Helicopters & Tanks & BBM & $\begin{array}{c}\text { Artillery } \\
\text { (Mortars) }\end{array}$ & Planes \\
\hline \multicolumn{8}{|c|}{ The first operation } \\
\hline \multirow{4}{*}{ RF } & №1 & 6567 & & 41 & 132 & 54 & - \\
\hline & №2 & 3915 & 14 & 34 & 165 & 62 & - \\
\hline & №3 & 4053 & 16 & 7 & 162 & 28 & - \\
\hline & $\mathrm{CPB}$ & 5200 & 17 & 10 & 125 & 36 & 515 \\
\hline \multicolumn{2}{|c|}{$\begin{array}{l}\text { Chechen } \\
\text { Republic }\end{array}$} & 35000 & 7 & 50 & 65 & $\begin{array}{c}35 \\
(150)\end{array}$ & $95^{*}$ \\
\hline \multicolumn{2}{|c|}{ Parties } & Personnel & Helicopters & Tanks & BBM & $\begin{array}{c}\text { Artillery } \\
\text { (Mortars) }\end{array}$ & Planes \\
\hline \multicolumn{8}{|c|}{ The second operation } \\
\hline \multicolumn{2}{|c|}{ CFG } & 172000 & 35 & 65 & 255 & 180 & 140 \\
\hline \multicolumn{2}{|c|}{$\begin{array}{l}\text { Chechen } \\
\text { Republic }\end{array}$} & 25000 & - & - & 78 & 12 & - \\
\hline
\end{tabular}

* - the number of serviceable aircraft.

As can be seen from table 4 In both the first and second operations in the Chechen Republic, the composition of groups of Russian troops ensured the achievement of the goal of the operation. But the specifics of the operations territory did not allow to fully realize the combat potential of the Russian Federation.

Table $\mathbf{5}$ - The composition of the forces of the parties in the military conflict between Russia and Georgia

\begin{tabular}{|c|c|c|c|c|c|c|}
\hline Parties & Planes & Helicopters & BBM & Tanks & $\begin{array}{c}\text { Ships } \\
\text { (boats) }\end{array}$ & Artillery (Mortars) \\
\hline AF RF & 425 & 55 & 1322 & 305 & 35 & 680 \\
\hline AF South Ossetia & - & 4 & 180 & 87 & - & 97 \\
\hline $\begin{array}{c}\text { AF } \\
\text { Abkhazia }\end{array}$ & 22 & 4 & 116 & 58 & - & 85 \\
\hline AF Georgia & 138 & 27 & 231 & 205 & 27 & 373 \\
\hline
\end{tabular}


In the military conflict between Russia and Georgia, the main form of use of the troops groupings was an offensive operation. The peculiarity of the use of the troops was that the combat actions were local in nature, without creating a solid front line. In addition, the Russian Federation used the latest models of weapons during the operation, from small arms to the "Iskander" missile system, which in turn helped to achieve the goal of the operation.

The results of the analysis of the data in table 5 show that the Russian Armed Forces together with the armed forces of the self-proclaimed republics had a significant advantage over the Georgian Armed Forces (advantage in combat potential 1: 8 ), respectively guaranteed the achievement of the "peace enforcement" operation.

\section{Conclusions}

Based on the results of the analysis, it was concluded:

a feature of modern operations is the increase in the speed of operations (combat operations), which are highly maneuverable defencive and offensive in nature;

during the use of troop groupings in operations, their composition did not remain constant during the operation and tended to increase;

\section{References}

Gareev M. (2003) Uroki i vyvody iz vojny v Irake. Voen. mysl'. № 8. S. 68-76.

Girin A. V. Vzglyady komandovaniya Armii SSHA na vedenie nastupleniya. - Available from: http://go.microsoft.com/fwlink/Linkld=69157

Kuchumov S. (2009) Vzglyady voennogo rukovodstva SSHA na primenenie Sukhoputnykh vojsk. Zarubezhnoe voennoe obozrenie. №1. S. 32-35.

Kulikov A. Balkanskaya strada. Operacziya OVS NATO "Reshitel naya sila" (Yugoslaviya, 24 marta - 10 iyunya 1999 g.). Vozd.-kosm. oborona. 2007. № 3 (34). S. 84-91.

Manachinskii A. Irak: tajnye pruzhiny vojny. Kyiv: 2005. $416 \mathrm{~s}$.

Mihajlov A. Irakskij kapkan. Moscow: Yauza, Ehksmo, 2004. $544 \mathrm{~s}$.

Myasnikov V. Vysokotochnoe oruzhie i strategicheskij balans. - Available from: www.armscontrol.ru/start/rus/publication/v to.html.

Operacziya OVS NATO protiv SRY "Soyuznicheskaya sila". Kyiv: CzNII VS Ukrainy', 1999. $124 \mathrm{~s}$ characteristic directions of the development of armed conflict and a significant number of conditions and factors influencing the preparation and conduct of the operation require careful consideration in determining the composition of the troop's groupings. That is why there is a need to analyze the main conditions and factors influencing the determination of the composition of the group of troops to conduct a defencive operation.
Strizhevs'kij V. V. Razvitie obshchej taktiki v lokal'nykh vojnakh vtoroj poloviny $\mathrm{KHKH}$ i nachale XXI vekov: monografiya / V. Strizhevs'kij. Kyiv: NAOU, 2006. 272 s.

Tkachev V. (2007) Perspektivnaya boevaya sistema Sukhoputnykh vojsk SSHA. Zarubezhnoe voennoe obozrenie. №4. S. 32-35. Tolubko V.B. Osnovnye zakonomernosti sovremennykh lokal'nykh vojn i vooruzhennykh konfliktov / V. B. Tolubko, YU. I. But, V. A. Kosevcov. Kyiv: NAOU, 2002. $68 \mathrm{~s}$. Ukaz Prizidenta Ukrainy` № 555/2015, O reshenii Soveta naczional 'noj bezopasnosti i oborony` ot 24 sentyabrya 2015 goda «O novoj redakczii Voennoj doktriny` Ukrainy`».

Voenno-politicheskij, strategicheskij, operativnyj i takticheskij smysl lokal'nykh vojn i vooruzhennykh konfliktov [Tekst]: posobie. / Pod red. V. B. Tolubko. Kyiv: NAOU, 2001. $226 \mathrm{~s}$.

Zaika V. F. Operativnoe iskusstvo inostrannykh armij: ucheb. posobie. / V. F. Zaika, A. N. Mishkov, N. N. Kuz'min i dr. Kyiv: NUOU, 2010. $92 \mathrm{~s}$. 